Michał Biela

ORCID: 0000-0002-3426-8959

\title{
Polityczny crowdfunding - innowacyjna forma wspierania kampanii politycznych i inicjatyw społecznych
}

Abstrakt: Celem niniejszego artykułu jest prezentacja założeń teoretycznych oraz praktycznej implementacji crowdfundingu w sferze społeczno-politycznej w Europie. W artykule ukazano perspektywę funkcjonalną (kto, jak, dlaczego, kiedy inicjuje polityczną kampanię crowdfundingową). Pierwsza część przedstawia kluczowe terminy, przegląd literatury oraz buduje ramy analityczne. Następnie analizie poddano europejskie polityczne projekty crowdfundingowe w kontekście ostatnich wydarzeń politycznych w Europie. W artykule jako metodę badawczą zastosowano analizę treści, której implementacja umożliwiła analizę istniejącej literatury przedmiotu.

Słowa kluczowe: crowdfunding, crowdsourcing, polityczny crowdfunding, kampanie online, brexit, polityka i Internet, komunikacja społeczna

\section{Political crowdfunding - an innovative form of supporting political campaigns and social initiatives}

Abstract: The purpose of this article is to present theoretical assumptions and practical implementation of crowdfunding in the socio-political sphere in Europe. The article presents a functional perspective (Who? How? Why? When is a political crowdfunding campaign initiated?). The first part of the article presents key terms, literature review and builds an analytical framework. Then, European political crowdfunding projects are analyzed in the context of recent political events in Europe. The article uses content analysis as the research method, the implementation of which has enabled the analysis of existing literature on the subject.

Keywords: crowdfunding, crowdsourcing, political crowdfunding, online campaigns, Brexit, politics and the Internet, social communication 


\section{Wstęp}

Crowdfunding to instrument ekonomii społecznej opierający się głównie na procesie przepływu środków finansowych, a także pomysłów, idei oraz informacji. Crowdfunding wywodzi się z koncepcji crowdsourcingu. Podstawową ideą crowdsourcingu jest pozyskiwanie informacji zwrotnych od dużej grupy osób. Crowdfunding, jako relatywnie nowa forma finansowania, jest atrakcyjnym sposobem wspierania przedsięwzięć gospodarczych i społecznych znajdujących się na wczesnym etapie rozwoju. Rozwój Internetu i platform społecznościowych „zmusił" polityków do odpowiedniej dywersyfikacji swoich strategii komunikacyjnych, które ze względu na trend związany z przeniesieniem części życia społecznego do Internetu w dużej mierze opierają się na nowoczesnych modelach finansowania społecznościowego ${ }^{1}$.

Od niedawna crowdfunding stał się popularnym sposobem gromadzenia środków finansowych na cele polityczne. Partie coraz chętniej wybierają polityczny crowfunding jako narzędzie wspierające poszczególne etapy kampanii politycznych, zapewniając tańszą alternatywę dla tradycyjnych metod. Silnym trendem jest intensyfikacja dyskursu politycznego poprzez jego wirtualizację, czyli umiejscowienie $\mathrm{w}$ internetowej przestrzeni dzięki wykorzystaniu narzędzi dostępnych w sieci. Poprzez użycie nowych technologii informacyjnych oraz komunikacyjnych możliwe jest budowanie internetowych społeczności, których oddziaływanie będzie widoczne zarówno w sieci, jak i w prawdziwym życiu. Kluczowym aspektem politycznego crowdfundingu są interakcje społeczne, które, pomimo że są mocno umiejscowione w wirtualnej rzeczywistości, zostają przeniesione do normalnego życia, gdzie ewoluują w tradycyjne grupy ludzi zorientowanych na działania wobec ugruntowanych celów oraz idei.

Celem niniejszego artykułu jest próba odpowiedzi na pytanie, co charakteryzuje crowdfunding stosowany przez partie polityczne oraz niezależnych kandydatów. Nie mniej ważne są inne pytania badawcze: czym jest polityczny crowdfunding, jakie działania podejmowane są $\mathrm{w}$ ramach politycznego crowdfundingu, jakie podmioty uczestniczą w politycznych kampaniach crowdfundingowych.

W artykule wykorzystano metodę analizy treści - było to podyktowane koniecznością analizy materiałów źródłowych, w szczególności deskrypcji politycznych projektów crowdfundingowych w Europie. Teoretycznym punktem odniesienia do podjętych rozważań jest dostępna wiedza politologiczna na tematy związane $\mathrm{z}$ procesami $\mathrm{w}$ zakresie przeprowadzania kampanii politycznych oraz komunikacji społecznej.

${ }^{1}$ R.K. Gibson, Party change, social media and the rise of 'citizen-initiated' campaigning, „Party Politics" 21, 2015, nr 2, s. 183-184. 


\section{Założenia definicyjne i koncepcyjne crowdfundingu politycznego}

Crowdfunding może być traktowany jako jedna $\mathrm{z}$ instytucji ekonomii społecznej, która opiera się na procesie przepływu dóbr, takich jak pieniądze, pomysły oraz informacje będące kluczowym elementem wczesnego etapu rozwoju różnego typu przedsięwzięć. System ten wykorzystuje „łłum” jako źródło pozyskiwania wymienionych zasobów oraz umożliwia tworzenie środowisk opartych na zasadzie zbiorowego podejmowania decyzji ${ }^{2}$.

Aby lepiej poznać ideę crowdfundingu, należy zrozumieć, czym jest crowdsourcing. Crowdsourcing polega na wykorzystaniu pomysłów oraz opinii, dzięki którym powstająca inicjatywa może zawierać w sobie ofertę bardziej wszechstronną i ukierunkowaną wobec szerszej grupy odbiorców. Dzięki crowdsourcingowi przedsiębiorca może pozyskiwać informacje na temat swojego produktu w czasie rzeczywistym, co pozwala na wydajniejszą kontrolę efektu końcowego ${ }^{3}$.

Termin „polityczny crowdsourcing” oraz „polityczny crowdfunding” to nowe koncepcje nauk politycznych. Brak jedności badawczej w interpretacji podstawowych pojęć, jak klasyczna koncepcja crowdsourcingu czy crowdfundingu, powoduje duże problemy przy definiowaniu fundamentów konceptualizacyjnych. Jednakże obecnie funkcjonujące trendy oraz mechanizmy współczesnej polityki są otwarte i bardzo chłonne na nowości, zarówno technologiczne, jak i organizacyjne, w szczególności te, które są w stanie pomoc w realizacji danej inicjatywy społecznej lub kampanii politycznej. Zauważa się wzrost roli udziału społeczeństwa w polityce, co jest ważnym determinantem rozwoju crowdfundingu politycznego. Zastosowanie mechanizmów politycznego crowdfundingu może być odpowiedzią na brak zasobów finansowych, jednocześnie podkreślając znaczenie zwykłych obywateli w procesach decyzyjnych zarówno na poziomie lokalnym, jak i krajowym czy nawet ponadnarodowym, jeżeli pod uwagę weźmiemy wpływ politycznego crowdfundingu między innymi na walkę z fake newsami podczas wychodzenia Wielkiej Brytanii z Unii Europejskiej czy wyborów do parlamentu europejskiego 4 .

Polityczny crowdsourcing miał duży wpływ na ewolucję crowdfundingu, który poprzez wzbogacenie go o cechy, na których bazuje polityczny crowdfunding, został uznany za nowy format dialogu społeczno-politycznego ${ }^{5}$.

${ }^{2}$ N. Scholz, The Relevance of Crowdfunding. The Impact on the Innovation Process of Small Entrepreneurial Firms, Manchester 2015, s. 10.

${ }^{3}$ R. Freund, How to overcome the barriers between economy and sociology with open innovation, open evaluation and crowdfunding?, „International Journal of Industrial Engineering and Management", Novi Sad 2010, s. 105-109.

4 J. Hemer, A snapshot on crowdfunding, „Working Paper Firms and Region” 2011, s. 8-17.

${ }^{5}$ N. Khoma, Technologies of Political (Socio-Political) Crowdsourcing and Crowdfunding: Word Experience and Steps Towards Implementation in Ukraine, Toruń 2015, s. 50-54. 
Polityczny crowdfunding rożni się od klasycznego tym, że jest jeszcze bardziej nastawiony na interakcję między zainteresowanymi oraz $\mathrm{w}$ znacznym stopniu opiera się na działaniach wykonywanych w czasie rzeczywistym, co umożliwia reagowanie i dopasowanie treści kampanii crowdfundingowej do obecnych potrzeb czy trendów na rynku politycznym. Polityczny crowdfunding rzadko kiedy jest utożsamiany z samą zbiórką na dany cel. Jego celem powinny być zmiany społeczne lub przedsięwzięcia, które będą mogły na przykład poprawić życie mieszkańców lub pobudzać demokrację. Kolejnym elementem odróżniającym klasyczny crowdfunding od politycznego jest to, że społeczność skupiona wokół danego problemu, który był tematem zbiórki, przenosi swoje zainteresowanie na osobę, która była organizatorem inicjatywy. Ten instrument alternatywnego finansowania jest skutecznym sposobem gromadzenia kapitału społecznego, politycznego oraz finansowego. Celem tej relatywnie nowej formy akumulowania zasobów materialnych i niematerialnych jest rozwój określonej inicjatywy społecznej o charakterze politycznym lub przedsięwzięcia niezwiązanego bezpośrednio z działalnością polityczną, jednakże mającego wspólny wymiar ideowy. Polityczny crowdfunding jest adekwatnym rozwiązaniem dla rozwoju przedsięwzięć politycznych lub prospołecznych, w szczególności na wczesnym etapie rozwoju. Pozwala on na przezwyciężenie początkowych trudności związanych z pozyskiwaniem zasobów, takich jak informacje zwrotne, zasoby ludzkie i środki finansowe, które umożliwią rozpoczęcie wdrażania projektu zgodnie z jego założeniami. Ponadto niwelowanie barier stojących naprzeciw rozwojowi danego przedsięwzięcia pozwala na zachowanie wysokiej dynamiki i tempa przebiegu zbiórki6.

Polityczny crowdfunding można zatem zdefiniować jako proces, w którym grupa ludzi dobrowolnie przekazuje relatywnie niewielkie kwoty pieniędzy na inicjatywę polityczną, partię polityczną lub polityka reprezentującego daną partię i zbierającego na cel związany z jej działalnością lub na swój własny o charakterze prospołecznym. Narzędzie to jest również używane przez niezależnych kandydatów, którzy dopiero chcą wejść do polityki, oraz przez działaczy społecznych, którzy wykorzystując crowdfunding polityczny oraz media społecznościowe, wspierają przemiany społeczne oraz pobudzają rozwój społeczeństwa obywatelskiego lub walczą z fake newsami ${ }^{7}$.

Crowdfunding polityczny można rozróżnić ze względu na:

1) strefę finansowania (wyborcza, antykorupcyjna),

2) naturę darowizn (finansowa, społeczna),

3) nagrodę oferowaną inwestorom (na przykład oznaczenie inwestorów w przemówieniu lub na stronie internetowej, możliwość uczestniczenia w działaniach partii politycznej, włączenie do listy wyborczej) $)^{8}$.

${ }^{6}$ Ibidem, s. 51-58.

7 International Institute for Democracy and Electoral Assistance, Online Political Crowdfunding Political Party Innovation Primer 2, International IDEA, Sweden 2018, s. 6.

${ }^{8}$ N. Khoma, op. cit., s. 55. 
Polityczny crowdfunding opiera się na założeniu, że osoba prawna, która zdecydowała się dobrowolnie wesprzeć potencjalną inicjatywę społeczną lub polityczną, będzie w dalszej kolejności aktywnie angażować się w wybraną przez siebie działalność polityczną, ponieważ jest z nią bezpośrednio związana. Przekazanie własnych zasobów finansowych lub pomysłów wzmaga bliskość z daną inicjatywą społeczną lub kampanią polityczną, ponieważ daje poczucie wpływu na przebieg przedsięwzięcia. Najważniejszym aspektem politycznego crowdfundingu jest budowanie relacji z darczyńcami, którzy mogą być identyfikowani jako potencjalni wyborcy. Kluczem do sukcesu jest kilkuetapowy proces budowania więzi społeczności zorientowanej na dany problem, która będzie widoczna również w rzeczywistości. Oznacza to, że partycypacja społeczności $\mathrm{w}$ daną inicjatywę polityczną lub społeczną nie będzie składać się jedynie na jednorazowe wpłaty pieniężne przez Internet. Nakłonienie kogoś do przekazania darowizny wiele razy, głosowania na konkretną aktywność polityczną lub przekonanie najbliższego otoczenia do przekazania darowizny na dany cel polityczny oznacza stworzenie pogłębionych więzi skupionych wokół danego przedsięwzięcia politycznego lub społecznego. Ważne jest zrozumienie grupy docelowej, co pozwoli na spersonalizowaną komunikację, która pomoże dotrzeć do jak największej liczby odbiorców i budować społeczność gotową partycypować zarówno w Internecie, jak i poza nim. Crowdfundingowy system może pokazać, że dana osoba dokonała wpłaty na jakiś cel. Zwiększa się przez to poczucie sprawcze przynależności do grupy i wkładu w rozwiązanie danego problemu ${ }^{9}-$ przez to ludzie są bardziej skłonni dokonywać wpłat nawet na cele, które relatywnie są im dalekie, jak na przykład pożary w Australii czy odbudowa katedry Notre Dame.

Profesjonalni crowdfunderzy podkreślają istotę budowania poczucia zaangażowania oraz przynależności darczyńców nawet w sytuacji, gdy początkowa aktywność polega jedynie na dobrowolnej darowiźnie na bliżej nieokreślony cel. Zauważają oni, że osoby, które są gotowe przekazać darowiznę raz, są często skłonne przekazać ją także w przyszłości; również chętniej angażują się w prace wolontaryjne na rzecz partii. Jest to też okazja do wytworzenia nowych więzi oraz zbudowania społeczności skupionej wokół danej inicjatywy politycznej lub społecznej. Osoby już w pełni zaangażowane, które dobrowolnie postanowiły przekazać pieniądze na rzecz wybranej partii, będą próbowały przekonać osoby ze swojej sieci kontaktów do podobnych działań. Dzięki internetowym narzędziom oraz swoistej naturze mediów społecznościowych każdy użytkownik jest w stanie wygenerować duże zasięgi swoim wpisem lub komentarzem ${ }^{10}$.

$\mathrm{W}$ zależności od tego, w jakim charakterze zostanie utworzona inicjatywa crowdfundingowa, będzie ona wpływać na docelową grupę odbiorców. Cel każdej zbiórki powinien być zorientowany tak, aby zebrać jak najwięcej środków finansowych w jak najkrótszym czasie. Crowdfunding polityczny skupia się jednak na

\footnotetext{
${ }^{9}$ R.K. Gibson, op. cit., s. 184-187.

${ }^{10}$ International Institute for Democracy and Electoral Assistance, op. cit., s. 13-16.
} 


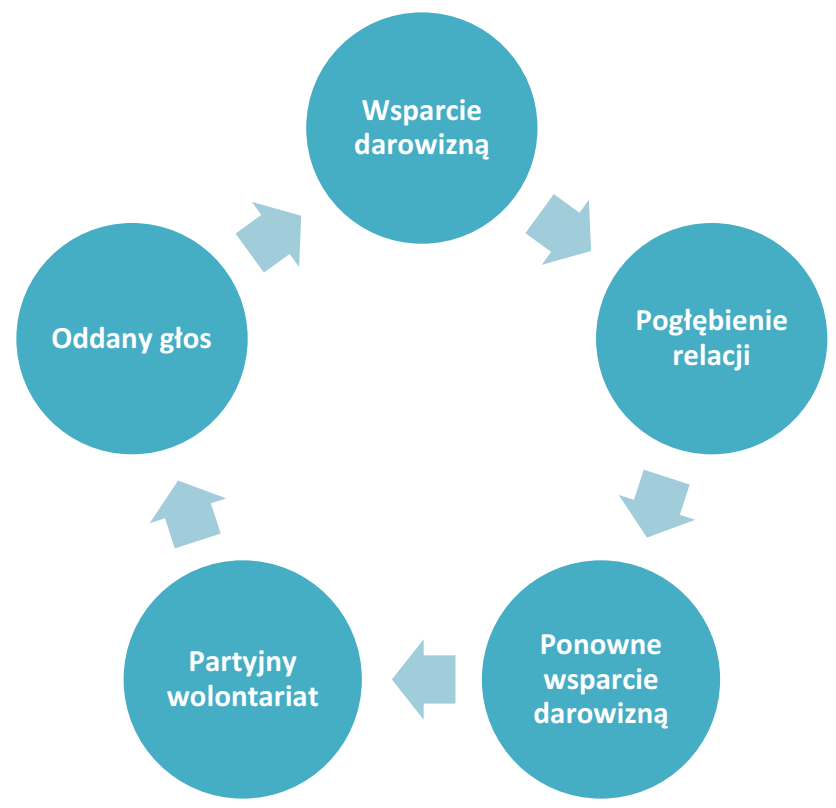

Wykres 1. Schemat działania politycznego crowdfundingu

Źródło: opracowanie własne na podstawie International Institute for Democracy and Electoral Assistance, Online Political Crowdfunding Political Party Innovation Primer 2, International IDEA, Sweden 2018.

dodatkowych ważnych czynnikach, co czyni go specyficznym narzędziem zarówno do gromadzenia kapitału, jak i komunikowania się z wybraną grupą osób. Aby pogłębiać więzi ze swoim elektoratem, partia polityczna w kampaniach crowdfundingowych będzie się skupiać na problemach bliskich sercu swoich wyborców. Działania podejmowane na rzecz danego przedsięwzięcia muszą być skuteczne, dlatego partia $\mathrm{z}$ dużym prawdopodobieństwem będzie opierać się na sprawdzonych wyborach i bazować na tematach, które są dla ich wyborców priorytetowe. Wielu badaczy podejmujących tematy z pogranicza politologii oraz psychologii uważa, że część zbiórek crowdfundingowych, w szczególności te o charakterze politycznym, bazuje na zamkniętych grupach odbiorców. Oznacza to, że zarówno informacje, jak i gromadzony kapitał zostają zamknięte i procesuje się je w relatywnie wąskim gronie ludzi, którzy są blisko związani z podmiotem inicjującym przedsięwzięcie. Jest to interesujące zjawisko, biorąc pod uwagę, że Internet oraz media społecznościowe umożliwiają wchodzenie w interakcje $\mathrm{z}$ olbrzymią liczbą osób ${ }^{11}$. Robert Putnam zwraca uwagę na to, że brak dodatkowych bodźców, które są ograniczane przez to, że część inicjatywy politycznego crowdfundingu odbywa się przez Internet, może determinować to, że silne, mniejsze społeczności rekompensują sobie w ten sposób deficyt związany z brakiem fizycznego kontaktu

11 A. Calderaro, Social media and politics, [w:] The SAGE Handbook of Political Sociology, red. W. Outhwaite, S.P. Turner, Cardiff 2018, s. 782-784. 
z grupą. W efekcie mniejsze społeczności mogą być bardzo dobrze zorganizowane dzięki lepiej rozwiniętym relacjom między poszczególnymi członkami grupy. Taka sytuacja może pozytywnie wpłynąć na tempo gromadzenia kapitału, bo osoby będą zapraszać do wzięcia udziału w inicjatywie swoich przyjaciół, oraz na to, $\mathrm{w}$ jakim stopniu zaangażowanie wniesione przez grupę w Internecie zostanie przeniesione na działania $\mathrm{w}$ terenie ${ }^{12}$.

Polityczny crowdfunding pozwala partii na większą niezależność finansową. Obniżenie progu wpłaty dla potencjalnego darczyńcy może przyczynić się do zmniejszenia wywierania wpływu na daną partię polityczną, podmiot polityczny lub inicjatywę polityczną przez dużych sponsorów. Mechanizm ten umożliwia pozyskiwanie niezależnych funduszy, ograniczając relacje ze sponsorami. Bazując na efekcie skali, możliwe jest stworzenie inicjatywy prospołecznej, która będzie odpowiadać dużej społeczności wspierającej dobrowolnie daną inicjatywę. Istotnym aspektem takiej formy finansowania jest to, że zgromadzony kapitał jest adekwatny do celów oraz założeń danej zbiorki, ponieważ poziom zaangażowania oraz finalna suma kapitału zgromadzona na poczet danej inicjatywy będzie odpowiadać realnemu poziomowi zainteresowania daną sprawą przez „tłum"13.

Sama darowizna może być jednym z sygnałów dla partii w kwestii rosnącego zainteresowania daną inicjatywą ze strony nowych potencjalnych zwolenników. Zarówno symboliczne, jak i rzeczywiste zobowiązanie na rzecz wybranej inicjatywy lub partii może przerodzić się w stałą współpracę pomiędzy podmiotami biorącymi udział w kampanii politycznego crowdfundingu. Kluczową kwestią determinującą takie zjawisko może być to, że osoba popierająca wybraną przez siebie kampanię społeczną lub polityczną jest bardziej skłonna poprzeć inicjatywę, która uosabia jej preferencje ideologiczne. To wspólna idea lub cel będzie podłożem do nawiązania więzi pomiędzy partią a osobą, która zdecydowała się wesprzeć wybraną kampanię crowdfundingową. Partia polityczna wspólnie z wyborcą może kreować komunikat, który będzie znaczący dla danej grupy odbiorców, w wyniku czego wyborcy mają szansę poznać działania partii poprzez ich realne zaangażowanie w sprawy bliskie obywatelom. Taki wyborca będzie również bardziej świadomy działań swojej partii, a sam wybór przynależności politycznej zostanie podyktowany pragmatycznymi determinantami. Polityczny crowdfunding umożliwia skuteczne budowanie zaufania i opinii publicznej. Ujawnianie informacji odnośnie do otrzymanego wsparcia za pomocą narzędzi crowdfundingowych pozwala zainicjować efekt kuli śnieżnej. Każdy kolejny transfer środków finansowych oraz wyrażona opinia czy sugestia powoduje, że kampania jest atrakcyjniejsza dla potencjalnego odbiorcy. Udostępnianie efektów oraz zakończonych inicjatyw przeprowadzonych dzięki wsparciu internetowego tłumu pozwala ukazać skale efektów oraz zachęcić osoby zaangażowane do dalszej współpracy. Możliwa jest także personalizacja obszaru tematycznego inicja-

12 R.D. Putnam, Bowling Alone: The Collapse and Revival of American Community, New York 2000.

13 International Institute for Democracy and Electoral Assistance, op. cit., s. 7. 
tywy w celu zaadresowania wiadomości do wyodrębnionej grupy odbiorców. Takie działanie może przyczynić się do pogłębienia istniejących więzi pomiędzy partią polityczną a tworzącą się społecznością. Istotnym elementem takiego zjawiska jest to, że nadawany komunikat jest silnie zorientowany na dominujące cechy danej grupy, przez co może być trudny w odbiorze dla osoby niebędącej częścią wybranej grupy ${ }^{14}$.

Polityczny crowdfunding może umożliwić budowanie kapitału politycznego kandydatowi, który nie ma dostatecznie wysoko rozwiniętych umiejętności interpersonalnych. Część kampanii będzie odbywać się poprzez narzędzia internetowe, a kandydat, który nie jest świetnym mówcą, może skupić się na działalności stricte funkcjonalnej. Pozwala to kandydatom zorientowanym na praktyczne działania brać udział w kreowaniu polityki lokalnej, która niekiedy jest mocno spolaryzowana i zdominowana przez populistyczne hasła ${ }^{15}$.

\section{Względy prawne i zagrożenia}

Polityczny crowdfunding może być wyzwaniem dla podmiotów monitorujących przepływy finansowe pomiędzy darczyńcami a partiami politycznymi. Tak skonstruowany model finansowania społecznościowego ma wiele obszarów do nadużyć, przez co może być interesującą formą gromadzenia kapitału dla podmiotów obracających się na politycznej arenie, które nie są zgodnie z prawem. W części państw Unii Europejskiej istnieją regulacje prawne odnoszące się do sposobu finansowania kampanii politycznych oraz różnego rodzaju działań prospołecznych o charakterze politycznym, których źródło finansowania nie jest przejrzyste lub jego ustalenie jest utrudnione. W państwach takich jak na przykład Stany Zjednoczone, które mają rozwinięte prawodawstwo w zakresie finansowania społecznościowego, osoby prawne oraz partie polityczne są zobligowane do zebrania relewantnych informacji na temat darczyńców w celu określenia ich intencji oraz ustalenia, czy poprzez przyjęcie przepływów finansowych w ramach danej inicjatywy nie dojdzie do złamania prawa ${ }^{16}$.

Oprócz względów prawnych ważną kwestią są aspekty związane z cyberbezpieczeństwem. Implementacja internetowych narzędzi w działania polityczne może nieść za sobą wiele potencjalnych zagrożeń. Część wrażliwych informacji, które będą zbierane podczas danej inicjatywy finansowej, może zostać wykorzystana przez politycznych przeciwników. Potencjalne zagrożenie może zostać zidentyfikowane również $\mathrm{w}$ obszarze działalności podmiotów pośredniczących w operacjach związanych z przepływem kapitału na rzecz danej inicjatywy crowdfundingowej. W tym obszarze szczególnie narażone na ataki hakerskie są platformy crowdfundingowe. Przez pryzmat potencjalnych zagrożeń dostrzega się skompli-

\footnotetext{
14 A. Calderaro, op. cit., s. 782-786.

15 Ibidem, s. 7-9.

16 International Institute for Democracy and Electoral Assistance, op. cit., s. 8-10.
} 
kowaną naturę politycznego crowdfundingu. Niektóre formy finansowania społecznościowego mogą również generować dodatkowe koszty związane z niewiedzą w zakresie narzędzi internetowych oraz potencjalnych zagrożeń. Niekiedy partie polityczne lub niezależni kandydaci nie są w stanie wejść na „polityczny rynek online”, ponieważ nie mają wystarczających zdolności informatycznych, aby rozpocząć tego rodzaju kampanię crowdfundingową. Dla polityka działającego lokalnie może się to okazać poważnym problemem, ponieważ w znaczny sposób ogranicza jego możliwości kreowania polityki lokalnej oraz komunikacji z lokalną społecznością ${ }^{17}$.

Partie polityczne, które wykorzystują nowoczesne technologie internetowe do pozyskiwania środków na finansowanie swojej działalności politycznej, są zobligowane do przestrzegania obowiązujących ram prawnych. Regulacje w zakresie finansowania partii politycznych w większości krajów odnoszą się do kwestii związanych $\mathrm{z}$ darowiznami w celu ograniczenia nielegalnych procederów, jak na przykład dzielenie dużych darowizn na mniejsze wpłaty finansowe poniżej wymogu progu zgłaszania kwot minimalnych w celu uniemożliwienia dotarcia do źródła finansowania. W państwach Unii Europejskiej partie polityczne są zobowiązane do zgłaszania darowizn powyżej określonego progu, aby zachęcić do wpłacania mniejszych darowizn; tym samym jednak umożliwiają monitorowanie transferów finansowych, które mogą zostać zidentyfikowane jako podejrzane lub niezgodne z prawem. W Wielkiej Brytanii, która ma wiele platform crowdfundingowych oraz wielu zwolenników tej metody pozyskiwania środków finansowych, darowizny poniżej 500 GBP nie muszą zostać odnotowane przez Komisję Wyborczą. Eksperci przewidują, że wraz ze wzrostem politycznego crowdfundingu wzrośnie również znaczenie niewielkich niezarejestrowanych kwot, w wyniku czego zmniejszy się siła oddziaływania dużych kwot finansowych pochodzących z jednego źródła. Takie zjawisko może mieć potencjalnie duży wpływ na sposób lobbowania przez dużych aktorów politycznych i gospodarczych na dane podmioty polityczne $e^{18}$.

Partie oraz niezależni crowdfunderzy mogą publikować szczegółowe listy osób angażujących się podczas trwania kampanii oraz po jej zakończeniu. Pozwala to między innymi zidentyfikować, czy mogło dojść do nadużyć finansowych lub prób wpłynięcia na przebieg kampanii crowdfundingowej. Możliwe jest prześledzenie źródła wpłat w celu ustalenia, czy nie doszło do podzielenia dużej kwoty finansowej na mniejsze datki w celu usiłowania zatajenia pierwotnego źródła finansowania. Odpowiednio wybrane narzędzia crowdfundingowe w połączeniu z przepisami dotyczącymi ochrony prywatności ułatwią ustanowienie solidnego systemu śledzenia kwalifikowalności darowizn ${ }^{19}$.

17 Ibidem, s. 10-13.

18 European Commission, Legislative proposal for an EU framework on crowd and peer to peer finance, Brussels 2018, https://ec.europa.eu/info/law/better-regulation/initiatives/ares-2017-5288649_ en (dostęp: 20.03.2020).

19 Ibidem. 
Polityczny crowdfunding pozwala zwiększyć poziom przejrzystości wydatków oraz przedstawić potencjalnym zainteresowanym skalę działań. Dzięki temu partia polityczna może efektywnie trafiać do bardziej wymagających wyborców. W części państw europejskich crowdfunding koliduje z regulacjami krajowymi, które zabraniają darowizn od osób trzecich lub anonimowych wpłat, niezależnie od ich wysokości. Rumuńska partia Związek Zbawienia Rumunii ${ }^{20}$ napotkała opór ze strony rumuńskiej komisji wyborczej, która uznała, że crowdfunding jest niezgodny $\mathrm{z}$ krajowymi przepisami przejrzystości w zakresie finansowania partii politycznych $^{21}$.

Crowdfunding polityczny, dzięki oparciu na technologii wykorzystującej Web 2.0, umożliwia wykorzystanie platform crowdfundingowych, które wymuszają rejestrację użytkowników przed dokonaniem wpłaty. Kampanie wykorzystujące fundrising umożliwiają dokonywanie wpłat przez niezarejestrowanych użytkowników, przez co sam system jest bardziej podatny na nadużycia ${ }^{22}$.

Platformy crowdfundingowe podczas procesu gromadzenia informacji mogą wejść w posiadanie danych na temat inicjatorów kampanii oraz strony finansującej wybrane przedsięwzięcie. Co istotne, wrażliwe dane należące do platformy crowdfundingowej mogą być niedostępne dla inicjatorów kampanii po zakończeniu zbiórki. Może to wynikać ze sposobu działania danej platformy crowdfundingowej oraz jej prywatnej polityki i krajowych regulacji w zakresie finansowania społecznościowego. Brak możliwości dotarcia do wszystkich danych, które zostały zgromadzone podczas zbiórki, uniemożliwia wyciągnięcie wszystkich wniosków, które mogą okazać się kluczowe do realizacji dalszych działań czy etapów kampanii. Ważne jest, aby strony były świadome, kto będzie właścicielem danych gromadzonych podczas przesyłania pieniędzy. Partie lub kandydaci zazwyczaj są zobligowani prawnie do prowadzenia rejestrów darowizn przekraczających określone kwoty. Dzięki temu zbiórka oraz wszystkie działania w obrębie kampanii crowdfundingowej będą legitymować się przejrzystym procesem, przez co sama kampania zostanie poprowadzona w sposób zgodny z prawem. Na ataki pod pretekstem braku przejrzystości oraz zasad etyki podczas swoich działań w Internecie narażone są w szczególności partie polityczne oraz niezależni kandydaci, którzy dopiero chcą wejść do polityki.

Istotną kwestią jest również sama komunikacja pomiędzy inicjatorem kampanii a zainteresowanymi. Osoby odpowiedzialne za przeprowadzenie zbiórki crowdfundingowej powinny poinformować potencjalnych darczyńców o obowiązujących przepisach. Informacja ta powinna zostać opublikowana na stronie partii lub kandydata, a jeżeli jest to możliwe, wiadomość powinna zostać podpięta na wszystkich platformach społecznościowych, na których prowadzone są działania

${ }^{20}$ Uniunea Salvati Romania.

${ }^{21}$ International Institute for Democracy and Electoral Assistance, op. cit., s. 10-12.

22 E. Gerber, P.Y. Kuo, Design principles. crowdfunding as a creativity support tool, ACM. In Proceeding CHI '12, Extended Abstracts on Human Factors in Computing Systems 2012, s. 1601-1606. 
informacyjne dotyczące kampanii crowdfundingowej. Unia Europejska aktywnie promuje i wspiera działania zwiększające dostępność informacji na temat źródeł finansowania danego przedsięwzięcia, jeżeli sama inicjatywa była sfinansowana przy wykorzystaniu nietradycyjnych metod gromadzenia kapitału, jak crowdfunding lub przy wykorzystaniu środków unijnych ${ }^{23}$.

Kampanie politycznego crowdfundingu pozwalają politykom na ciągłe rozpowszechnianie informacji o swoich działaniach. Potencjalnym zainteresowanym umożliwiają śledzenie aktywności danego polityka, a inicjatorom - nadawanie komunikatu zidentyfikowanego jako „otwarte zaproszenie” ${ }^{24}$, przez co każda osoba może zostać potencjalnym darczyńcą. W istocie kluczowym aspektem, który determinuje skuteczność kampanii crowdfundingowych, jest możliwość nawiązywania bezpośredniego kontaktu z wyborcami, co znacznie ułatwia zwiększenie poziomu zaangażowania zainteresowanych stron we wspieraniu wybranego kandydata $^{25}$.

\section{Narzędzia i instrumenty politycznego crowdfundingu}

Innowacje technologiczne umożliwiły obniżenie kosztów związanych z działaniami organizacyjnymi w zakresie prowadzenia strategicznych operacji politycznych. Istotnym przełomem dla wielu mniejszych podmiotów politycznych okazała się możliwość gromadzenia środków finansowych przy równoczesnym komunikowaniu się z darczyńcami w celu sfinansowania danego przedsięwzięcia prospołecznego. Platformy crowdfundingowe oraz portale społecznościowe okazały się potężnym instrumentem zarówno do gromadzenia kapitału, jak i utrzymywania komunikacji ze swoim elektoratem przez partie polityczne oraz niezależnych kandydatów w czasie rzeczywistym. Umożliwia to szybkie reagowanie na zmieniające się trendy oraz społeczne zapotrzebowania (w szczególności na poziomie lokalnym), co może pozytywnie wpłynąć na sposób postrzegania danego kandydata przez lokalną społeczność ${ }^{26}$.

Crowdfunding jest bezpośrednio związany z rewolucją informacyjną i komunikacyjną, ponieważ działa przede wszystkim w sieciach społecznościowych. Wsparcie jest okazywane przez polubienia i udostępnienia postu. Beppe Grillo ${ }^{27}$ dzięki tej technologii zyskał na popularności w sieci, co pomogło mu w rozwinię-

23 International Institute for Democracy and Electoral Assistance, op. cit., s. 12-13.

24 W literaturze podmiotu crowdfunding często określa się jako system „otwartego zaproszenia”, co ma oddać istotę charakteru finansowania społecznościowego, w którym to każdy zainteresowany ma możliwość partycypacji.

25 P. Belleflamme et. al., Crowdfunding: Tapping the right crowd, „Journal of Business Venturing" 2014, s. 7-8.

${ }^{26}$ R.K. Gibson, op. cit., s. 184-186.

27 Włoski aktor oraz działacz polityczny, założyciel partii Ruch Pięciu Gwiazd. 
ciu kariery politycznej. Skuteczność kampanii politycznej często zależy od ilości zabranych funduszy. Crowdunding polityczny pozwala na uzyskanie nawet $80 \%$ budżetu kampanii politycznej; może także pomóc w uniknięciu wysokich kosztów rozpoczęcia kampanii. Inwestorzy w zamian za swoje wpłaty nie otrzymują zwrotów gotówkowych ani udziałów w przedsiębiorstwie, zamiast tego mogą liczyć na nagrodę w postaci na przykład publicznych podziękowań ${ }^{28}$.

Partia Aam Aadmi w Indiach stworzyła aplikację mobilną na telefon, która pozwala na przekazywanie bezpośrednich darowizn na konto ugrupowania $\mathrm{w}$ celu wsparcia danej inicjatywy. Pomysłodawcy podkreślali, że aplikacja to odpowiedź na rosnące znaczenie smartfonów, które obecnie swoją mocą obliczeniową przewyższają niejednokrotnie komputery stacjonarne czy laptopy. Dodatkowym atutem jest to, że smartfon jest używany znacznie częściej niż komputer w codziennym życiu, przez co potencjalny darczyńca ma dostęp do większej ilości informacji związanej z działalnością wybranej partii. Warto podkreślić, że w ten sposób zostaje ułatwiona komunikacja pomiędzy zainteresowanymi podmiotami oraz może się ona odbywać w sposób ciągły. System powiadomień w takich aplikacjach pozwala komunikować się inicjatorom kampanii z darczyńcami, wysyłając im ważne treści, które w tym samym momencie zostaną wyświetlone na ich smartfonach. W dynamicznym świecie polityki, w którym w każdym momencie pojawia się wiele fake newsów, a różne ugrupowania polityczne na wiele sposobów zabiegają o przeciągnięcie na swoją stronę potencjalnego wyborcy, oddziaływanie w czasie rzeczywistym, przy jednoczesnej możliwości otrzymania relatywnie szybkiej informacji zwrotnej, jest niezwykle istotne ${ }^{29}$.

W 2016 roku amerykański polityk Ted Cruz wykorzystał aplikację mobilną w wyścigu po fotel prezydenta Stanów Zjednoczonych. Aplikacja bazowała na systemie, w którym zainteresowani zbierali punkty za polubienia, udostępnienia oraz pisanie komentarzy pod wyznaczonymi postami w mediach społecznościowych. Cały proces polegał na tym, aby nakłonić jak największą liczbę osób do przekazania darowizny na kampanię Teda Cruza. Wykorzystanie finansowania społecznościowego oraz aktywnego zaangażowania użytkowników portali społecznościowych przyczyniły się do zebrania 26,6 milionów USD na poczet jego kampanii politycznej ${ }^{30}$.

Popularna metoda gromadzenia kapitału przez partie polityczne, która ostatnio coraz częściej jest wybierana, w szczególności przez mniejsze partie, opiera się na procesie, w którym to niewielkie darowizny są przekazywane na niesprecyzowany cel. Cały proces odbywa się poprzez kliknięcie odpowiedniej opcji na stronie internetowej partii politycznej lub niezależnego kandydata. W tym przypadku istotnym zjawiskiem jest to, że partia swoim działaniem zwiększa zasięgi oraz potencjalną bazę wyborców. Pozwala to intensyfikować działania związane z poszerzaniem bazy

\footnotetext{
${ }^{28}$ N. Khoma, op. cit., s. 54-57.

${ }^{29}$ International Institute for Democracy and Electoral Assistance, op. cit., s. 14.

${ }^{30}$ Ibidem, s. 14.
} 
swoich wyborców niższym kosztem. Efektem będzie również zwiększony zasięg komunikatu, który wysyła partia, przez co także zwiększa się ich oddziaływanie na scenie politycznej. W przypadku partii uznawanych za populistyczne pozwala to w sposób ciągły nadawać jasny przekaz, który nie zostałby przekazany przez tradycyjne media. Polityczny crowdfunding pozwala partiom prowadzącym nadawać komunikat, który dzięki wykorzystaniu nowych internetowych technologii nie zostanie odrzucony ${ }^{31}$.

Czeska Partia Piratów otrzymała wsparcie finansowe od „internetowego tłumu" podczas wyborów w 2017 roku do parlamentu krajowego. Głównym celem kampanii crowdfundingowej był zakup łodzi, która miała być swoistym symbolem kampanijnym partii. Łódź pływała wzdłuż rzeki Wełtawy, a jej zadaniem była wizualizacja wizerunku partii. Pomysł pirackiej łodzi wzbudził duże zainteresowanie, które zostało odnotowane nie tylko w grupach stałego elektoratu partii. Sukces nie ograniczał się jedynie do sfinansowania inicjatywy promocyjnej kampanii, lecz także ukazał skuteczność w posługiwaniu się relatywnie nowymi narzędziami finansowania oraz to, że partia jest $\mathrm{w}$ stanie skutecznie komunikować się z potencjalnymi wyborcami ${ }^{32}$.

Partie polityczne coraz częściej wykorzystują narzędzia crowdfundingowe w celu ilustracji tego, jak duże jest ich poparcie oraz na ile zebrane kwoty finansowe pokrywają się w rzeczywistości z poparciem politycznym. Premier Austrii Sebastian Kurz na swojej stronie internetowej zestawił katalog wydatków wraz z określonymi kwotami potrzebnymi na ich realizację. W wielu przypadkach kwoty nie pokrywały się z założonymi celami, a były jedynie przykładem potencjalnych wydatków ${ }^{33}$.

Celem takiego działania jest bezpośrednie wsparcie danej inicjatywy, a pośrednio transfer części środków finansowych na inny cel, który nie jest na tyle popularny, aby mógł być tematem niezależnego przedsięwzięcia crowdfundingowego.

Hiszpańska partia Podemos za pomocą crowdfundingu w latach 2014-2017 zgromadziła kapitał o wysokości około 885 tys. euro. Podemos korzysta z modelu crowdfundingu, który pozwala na zatrzymanie wpłat, nawet gdy cel nie zostanie zrealizowany, czyli nie otrzyma minimalnego wsparcia finansowego umożliwiającego pełną realizację założeń projektowych. Dzięki takiemu modelowi crowdfundingu partia redukuje ryzyko niepowodzenia wybranej kampanii crowdfundingowej poprzez transfer środków finansowych na inny cel. Partia publikuje również swoje sprawozdania finansowe $\mathrm{w}$ zakresie transferów środków pieniężnych na podstawie

${ }^{31} \mathrm{~K}$. de Buysere et al., A framework for European crowdfunding, European Crowdfunding Network 2012, http://eurocrowd.org/wp-content/blogs.dir/sites/85/2013/06/FRAMEWORK_EU_ CROWDFUNDING.pdf (dostęp: 21.03.2020).

32 Pirate Party, Czechia, Začíná pirátská plavba do Sněmovny (A pirate voyage begins in the Chamber of Deputies), 2017, https:/www.pirati.cz/tiskove-zpravy/piratska-lod-vyplouva.html (dostęp:21.03.2020).

33 Oberösterreichische Nachrichten, Austria, Kurz betreibt Crowdfunding (Kurz announces crowdfundingu), 2017, http://www.nachrichten.at/ nachrichten/politik/innenpolitik/Kurz-betreibtCrowdfunding;art385,2612125 (dostęp: 21.03.2020). 
wpływów z finansowania społecznościowego. Taka forma ujawniania swoich dochodów przez partie może być wyrazem nadzoru obywatelskiego oraz uzupełnieniem regulacji w zakresie ujawniania informacji na temat przychodów finansowych partii ${ }^{34}$.

Duża przejrzystość finansów partii wpływa pozytywnie na budowanie zaufania wśród wyborców, przez co może mieć ogromny wpływ na wygrywanie wyborów, w szczególności w krajach, gdzie istnieją silne związki korupcyjne powiązane z władzą. Polityczny crowdfunding umożliwia budowanie zaufania poprzez ukazywanie przez partie w czasie rzeczywistym, na co przeznaczana jest część dochodów zebranych dzięki finansowaniu społecznościowemu. W znaczny sposób wpływa to na poziom wiarygodności i wzmacnia odpowiedzialność partii przed wyborcami. Dodatkowym następstwem jest to, że partia częściej pojawia się w wyszukiwarkach i lepiej pozycjonuje się w Internecie, ponieważ kampanie crowdfundingowe, które są inicjowane na popularnych platformach, zapewniają duży ruch użytkowników ${ }^{35}$.

Simone Natale i Andrea Ballatore zauważają, że wykorzystanie przez polityków oraz działaczy społecznych platform społecznościowych do mikrob logowania dynamicznie wzrasta. Platformy crowdfundingowe, będące często integralną częścią serwisów społecznościowych, są jednym z takich narzędzi i również pozwalają zwiększyć konkurencyjność oraz efektywność danej kampanii politycznej czy przedsięwzięcia społecznego ${ }^{36}$. Pippa Norris zauważa, że wzmożony udział społeczeństwa w decyzyjnym procesie politycznym jest ważną częścią współczesnej demokracji. Polityczny crowdfunding oraz swoista natura platform crowdfundingowych, przy uwzględnieniu znacznego dostępu do Internetu, umożliwia partycypowanie w życie społeczne. Dzięki ułatwionemu dostępowi do możliwości przekazania swoich zasobów w postaci informacji, wiedzy lub środków finansowych dana jednostka może jednocześnie uczestniczyć w kilku kampaniach społecznych, które będą zorientowane na wspólny cel. Możliwość zarówno intensyfikacji, jak i dywersyfikacji działań w tym kontekście pozwoli skutecznie wspierać między innymi oddolne inicjatywy w zakresie walki o prawa osób wykluczonych z życia politycznego czy nawet objętego wojną ${ }^{37}$. Bart Cammaerts zwraca uwagę, że dobrze funkcjonująca demokracja nie opiera się jedynie na efektywnej władzy wykonawczej i ustawodawczej, lecz także na partycypacji szeroko rozumianego społeczeństwa obywatelskiego, które dzięki Internetowi może przybierać różne kształty. Może także w uproszczony sposób wpływać na rzeczywistość zarówno natury społecznej, jak i politycznej ${ }^{38}$. Jay Blumler i Stephen Coleman wskazują,

${ }^{34}$ International Institute for Democracy and Electoral Assistance, op. cit., s. 16.

35 A. Calderaro, op. cit., s. 790-792.

36 S. Natale, A. Ballatore, The web will kill them all: New media, digital utopia, and political struggle in the Italian 5-star movement, „Media, Culture \& Society” 2014, s. 105-121.

37 P. Norris, A Virtuous Circle: Political Communications in Postindustrial Societies, Cambridge 2000, s. 2-5.

38 B. Cammaerts, Internet-Mediated Participation Beyond the Nation State, Manchester 2008, s. $8-12$. 
że Internet oferuje wiele autonomicznych kanałów komunikacji, które ewoluują, przez co możliwe jest tworzenie ruchów społecznych zorientowanych na dany cel oraz mających swoje idee i chęć do aktywnej partycypacji. Interesujące jest, że polityczny crowdfunding może zostać zainicjowany zarówno przez niezależnego kandydata, jak i w wyniku oddziaływania różnego rodzaju form oddolnych oraz odgórnie przez partię. Kierunek, z jakiego wyjdzie impuls do zapoczątkowania danej kampanii, będzie determinować jej potencjalny przebieg. Następstwem takiego działania może być próba wpłynięcia na opinię publiczną poprzez uwydatnienie wybranego problemu społecznego lub politycznego. Podczas wychodzenia Wielkiej Brytanii z Unii Europejskiej osoby sprzeciwiające się brexitowi inicjowały oraz uczestniczyły w kampaniach crowdfundingowych. Rezultatem tych działań były zbiórki mające na celu zebranie środków finansowych na informacyjną walkę $\mathrm{z}$ fake newsami czy pomoc $\mathrm{w}$ politycznej agitacji na rzecz zostania Wielkiej Brytanii w Unii Europejskiej ${ }^{39}$. Andrea Calderaro podkreśla rolę alternatywnych internetowych form komunikacji, które mogą być jedynym niezależnym strumieniem komunikacji, w sytuacji gdy media w danym kraju są mocno uzależnione od poszczególnych stron konfliktu politycznego ${ }^{40}$.

Polityczny crowdfunding umożliwia ruchom oddolnym kreowanie polityki na poziomie lokalnym, bez uwzględniania partii politycznej w tym procesie. Zjawisko można zaobserwować w krajach, które są ogarnięte znacznym poziomem korupcji, oraz mających niedostatecznie rozwinięty trójpodział władzy, w których nie występują procesy demokratyzacji oraz nie szanuje się praw człowieka. Philip Howard i Muzammil Hussain wskazują, że współczesne narzędzia internetowe umożliwiają dowolnym osobom wchodzenie we wzajemne interakcje oraz budowanie społeczności. Dodatkowym atutem politycznego crowdfundingu, który może dopełnić funkcjonalności platform społecznościowych, jest wymiana doświadczeń $\mathrm{z}$ osobami mającymi dużą wiedzę $\mathrm{w}$ danym zakresie ${ }^{41}$.

Bezpośrednim celem politycznego crowdfundingu jest zbieranie środków finansowych od zaangażowanych w zbiórkę dawców. Jednakże następstwem każdej inicjatywy czy kampanii crowdfundingowej powinno być wzmocnienie więzi między partią, niezależnym kandydatem czy działaczem społecznym a podmiotami powiązanymi.

Niezależnie od wybranego modelu crowdfudingu inicjator zbiórki powinien określić strategię informacyjną, w której znajdą się wszystkie niezbędne założenia odnoszące się do procesu przekazywania środków finansowych, pozwalające potencjalnemu zainteresowanemu na przekazanie kwoty na wybrane przez siebie przed-

39 J.G. Blumler, S.J. Coleman, The Internet and Democratic Citizenship: Theory, Practice and Policy, Cambridge 2009.

40 A. Calderaro, Internet Governance Capacity Building in Post-Authoritarian Contexts. Telecom Reform and Human Rights in Myanmar, New York 2015.

${ }^{41}$ P.N. Howard, M.M. Hussain, Democracy's Fourth Wave?: Digital Media and the Arab Spring, New York 2013. 
sięwzięcie. Adekwatny plan komunikacji, informujący grupy docelowe o inicjatywie pozyskiwania funduszy, będzie silnym bodźcem początkowym umożliwiającym nadanie dynamiki całej kampanii. W tym miejscu warto podkreślić, jak ważna jest wiedza z zakresu komunikacji oraz internetowych narzędzi finansowania. Doświadczony crowdfunder, który ma wiedzę z zakresu finansowania społecznościowego oraz umiejętności w budowaniu społeczności internetowych zorientowanych na dany problem, będzie bardziej skuteczny w swoich kampaniach crowdfundingowych. Posiadanie kapitału w postaci stałej grupy odbiorców, która jest zaangażowana w kolejne inicjatywy crowdfundingowe, pozwala znacznie szybciej finansować zbiórki oraz sprawniej obierać kolejne cele do sfinansowania. Jednakże zbyt częste proszenie o darowizny może skutkować „zmęczeniem dawcy”, przez co nie tylko nie będzie chciał on podnosić poziomu swojego zaangażowania, lecz także nie będzie zainteresowany wsparciem następnych zbiórek crowdfundingowych własnym kapitałem finansowym. Istnieje również zależność objawiająca się poziomem zaangażowania a reakcją na ponowne wezwanie do przekazania darowizny. Jeśli dana osoba wspiera konkretnego polityka lub działacza społecznego przez dłuższy czas oraz z większą częstotliwością, jest bardziej skłonna zaangażować się w kolejną kampanię, dlatego istotne jest wybieranie odpowiedniej grupy docelowej podczas konstruowania celów kampanii crowdfundingowej oraz skupianie się na budowaniu stałej bazy zaangażowanych osób ${ }^{42}$.

\section{Pozycja wykluczonych i mniej wpływowych grup}

Polityczny crowdfunding pozwala partycypować w życiu politycznym osobom, które zostały z niego wykluczone. Dzięki mechanizmom finansowania społecznościowego oraz platformom społecznościowym umożliwiającym zakładanie internetowych grup zorientowanych na dany społeczny problem osoba wykluczona może nie tylko zostać darczyńcą i wspierać wybraną przez siebie inicjatywę, ale także sama stać się inicjatorem zmian w swoim lokalnym środowisku społecznym i politycznym. Wiele warunków pozwalających obywatelom ubiegać się o urzędy polityczne jest zależnych oraz mocno zdeterminowanych dostępnym kapitałem finansowym, który dany kandydat jest w stanie przeznaczyć na swoją kampanię. W szczególności kobiety, jako grupa mająca zazwyczaj mniejszy kapitał od mężczyzn, mają trudniejszą drogę podczas uruchamiania poszczególnych etapów kampanii, co w znaczny sposób utrudnia im konkurowanie na równych warunkach. Pomagając kandydatom w budowie politycznego kapitału oraz widoczności publicznej, „tłum” poprzez crowdfunding umożliwia wprowadzenie do dyskursów publicznych ważnych tematów, które niejednokrotnie spotykają się z dużym oporem, gdy są poruszane w tradycyjnych mediach lub niezgodnie z nurtem aktualnie rządzącej większości

42 A. Calderaro, op. cit., s. 784-789. 
w danej społeczności. Polityczny crowdfunding może być tym samym potężnym narzędziem do pozyskiwania funduszy dla osób pozbawionych praw obywatelskich ${ }^{43}$.

$\mathrm{Na}$ Wschodzie Europy można zauważyć zwiększenie znaczenia oraz potencjału małych inwestorów dla zbiórek politycznego finansowania społecznościowego. Opozycja w Rosji wykorzystuje crowdfunding polityczny do finansowania swoich kampanii, które mogą istnieć głównie dzięki wpłatom darczyńców, ponieważ z powodu swoich antyrządowych treści nie mogą liczyć na inne źródło finansowania. Przykładem takiego przedsięwzięcia jest na przykład PussyRiot ${ }^{44}$, która wielokrotnie korzystała z prowadzenia kampanii crowdfundingowej za pośrednictwem strony Kickstarter.com. Następnym przykładem jest utworzona przez Aleksieja Nawalnego w 2011 roku platforma internetowa RosPil.net ${ }^{45}$ zajmująca się walką z korupcją wśród rosyjskich urzędników państwowych. Organizacja jest finansowana wyłącznie $\mathrm{z}$ datków swoich zwolenników ${ }^{46}$.

Polityczny crowdfunding wybierany przez partie polityczne, polityków oraz działaczy społecznych jako narzędzie do wspierania poszczególnych etapów kampanii politycznych i inicjatyw prospołecznych jest coraz częstszą formą zarówno finansowania, jak i budowania konkurencyjności. Mimo że coraz więcej partii politycznych oraz niezależnych kandydatów używa narzędzi crowdfundingowych jako metody finansowania swoich kampanii, to wciąż brakuje dowodów empirycznych ukazujących skuteczność mechanizmów crowdfundingowych jako kluczowego narzędzia, które znacznie wpływa na wyniki wyborów zarówno na poziomie lokalnym, jak i krajowym ${ }^{47}$.

\section{Procesy politycznego crowdfundingu w Wielkiej Brytanii}

W Wielkiej Brytanii polityczny crowdfunding okazał się atrakcyjnym narzędziem finansowania kampanii politycznych. Podczas wyborów do krajowego parlamentu w 2017 i 2019 roku skorzystali z niego prawica, lewica oraz centryści. Biorąc pod uwagę niewielkie wsparcie, jakie dostają partie od rządu centralnego, może okazać się to kluczową formą finansowania dla mniejszych podmiotów politycznych. Ponadto system premiuje większe partie przy rozdzielaniu subwencji ${ }^{48}$,

\footnotetext{
43 International Institute for Democracy and Electoral Assistance, op. cit., s. 18.

44 Powstała w 2011 roku grupa feministyczna, znana z protestów politycznych.

45 Obecnie istnieje pod nazwą https://fbk.info/.

46 N. Khoma, op. cit., s. 54-58.

47 Ibidem, s. 55-58.

48 Kwota przyznawana partiom przez rząd jest uzależniona od liczby mandatów danej partii w Izbie Gmin.
} 
przez co alternatywne źródła finansowania mogą być niezwykle istotne dla mniejszych partii oraz niezależnych kandydatów ${ }^{49}$.

Ron Johnston oraz Charles Pattie wskazują w swoich badaniach, że od 2014 roku partie polityczne w Wielkiej Brytanii coraz częściej korzystają z narzędzi crowdfundingowych - zarówno w okresie kampanii wyborczych, jak i finansując społeczne inicjatywy. Warto zwrócić uwagę, że w Wielkiej Brytanii znajduje się największy sektor finansowania społecznościowego w całej Europie ${ }^{50}$.

Seth Hill i Gregory Huber wskazują zaś, że silna narracja oraz konkretne uwypuklenie problemów relewantnych z punktu widzenia wyborców danej opcji politycznej wpływa pozytywnie na przebieg finansowania danej zbiórki ${ }^{51}$. Jak wynika z badań przeprowadzonych przez Hansa Hassella oraz Quina Monsona osoby o poglądach prawicowych lub lewicowych częściej angażują się w kampanie crowdfundingowe niż osoby identyfikujące się jako centryści ${ }^{52}$.

Istnieje wiele korzyści wynikających z piastowania mandatu poselskiego w momencie uruchomienia kampanii crowdfundingowej. Jedną z nich jest budowanie wiarygodnego wizerunku, w wyniku czego inicjatywy jawią się wyborcom jako profesjonalne $\mathrm{i}$ bardziej osiągalne $\mathrm{w}$ realizacji. Zostało to również odnotowane w badaniach przeprowadzanych podczas wyborów do Izby Niższej w Wielkiej Brytanii w 2017 roku. Parlamentarzyści ubiegający się o reelekcję mieli większe szanse na zebranie ustalonej kwoty niż kandydaci spoza establishmentu politycznego. W badaniu zostało uwzględnionych stu kandydatów do parlamentu brytyjskiego. Spośród trzydziestu siedmiu osób ubiegających się o reelekcję 78\% osiągnęło swój cel finansowy. Dla kandydatów niezasiadających w Izbie Niższej wartość ta wyniosła 51\%. Badacze wskazują, że na taki wynik miało wpływ wiele elementów. Politycy, którzy poprzez zbiórki crowdfundingowe chcieli przypomnieć o sobie szerszej publiczności, skupiali się na tym, aby zwrócić na siebie uwagę poprzez ukazanie danego problemu przy relatywnie niskim celu finansowania. $\mathrm{W}$ rezultacie tej grupie łatwiej było uzyskać wymaganą kwotę finansowania, potrzebną do realizacji wyznaczonego celu. Osoby, którzy kandydowały z ramienia partii mającej mniejszy budżet, wykazywały silniejszą motywację w kierunku uzyskania większej ilości środków finansowych. W rezultacie ponad połowa wszystkich projektów osiągnęła założoną kwotę finansowania, a około jedna piąta uzyskała więcej środków finansowych niż planowała. Warto również zwrócić uwagę, że w Wielkiej Brytanii polityczny crowdfunding cechuje się relatywnie niskimi celami finansowania. W badaniu przeprowadzonym przez Solange Pompl i Sergiu Gherghina podczas

49 S. Pompl, S. Gherghina, Messages and Familiar Faces: Crowdfunding in the 2017 U.K. Electoral Campaign, „Politics \& Policy” 47, 2019, nr 3, s. 438-441.

${ }^{50}$ R. Johnston, C. Pattie, Money and Electoral Politics: Local Parties and Funding at General Elections, Bristol 2014, s. 4-9.

51 S.J. Hill, G.A. Huber, Representativeness and motivations of the contemporary donorate: Results from merged survey and administrative records, „Polit Behav” 39, 2017, s. 4-19.

52 H.J.G. Hassell, J.Q. Monson, Campaign targets and messages in direct mail fundraising, „Polit Behav" 36, 2014, s. 360-370. 
wyborów do parlamentu krajowego w 2017 roku wartości oscylowały pomiędzy 500 a 20 tysięcy funtów. Ukazuje to swoisty charakter politycznego crowdfundingu w Wielkiej Brytanii, który w dużej mierze nastawiony jest na komunikację i wchodzenie w interakcję z wyborcami. Kontrastuje to z modelem amerykańskim, gdzie politycy potrafią uzyskać wsparcie w wysokości przekraczającej miliony dolarów. Badawcze wskazują, że kandydaci, którzy informowali opinię publiczną o postępach w realizacji zbiorki crowdfundingowej za pomocą swoich mediów społecznościowych częściej otrzymywali dodatkowe wsparcie finansowe ${ }^{53}$.

Pojawiające się $\mathrm{z}$ dnia na dzień nowe fake newsy w okresie wychodzenia Wielkiej Brytanii z Unii Europejskiej zmobilizowały ludzi do zajęcia stanowiska, dzieląc społeczeństwo na zwolenników i przeciwników brexitu. Freedman i Goldstein wskazują, że implementacja negatywnego dyskursu może znacząco wpłynąć na przebieg danej kampanii, ponieważ stymuluje społeczeństwo do podejmowania działań. Od 23 czerwca 2016 roku do 31 stycznia 2020 roku na portalach społecznościowych pojawiło się łącznie 318 milionów postów z hasztagiem „brexit”54.

Lewicowi oraz liberalni działacze wykorzystali narzędzia politycznego crowdfundingu $\mathrm{w}$ walce $\mathrm{z}$ dezinformacją na rzecz brexitu. Na kampanię informacyjną odnoszącą się do pozostania Wielkiej Brytanii w Unii Europejskiej udało się zebrać 611102 tysięcy GBP dzięki platformie crowdfunder.co.uk. pomiędzy 29 kwietnia 2016 roku a 23 grudnia 2019 roku. We wszystkich zbiórkach uczestniczyło 21224 osób, a ustalone kwoty umożliwiające realizację celów zbiórki zaczynały się od 130 GBP, a kończyły na 221670 GBP55.

Co istotne, zbiórka na pierwszą kampanię informacyjną rozpoczęła się jeszcze przed wynikiem referendum. Celem finansowania miała być akcja informacyjna skierowana do wszystkich obywateli, dotycząca potencjalnych skutków wyjścia Wielkiej Brytanii z Unii Europejskiej. Full Fact to niezależna, bezstronna, organizacja charytatywna z Wielkiej Brytanii, która w tym celu w ciągu 36 dni zebrała 43260 GBP dzięki 1371 darczyńcom ${ }^{56}$.

Kolejnym zrealizowanym projektem był czerwony autobus, który został obklejony odpowiedziami dementującymi najbardziej popularne fake newsy. Autobus jeździł po całym kraju i miał pełnić funkcję informacyjną. Cała inicjatywa była reakcją na autobus Borisa Johnsona, który to pojazd został obklejony informacjami jakoby Wielka Brytania wysyłała 350 milionów GBP cotygodniowo do Unii Europejskiej zamiast transferować je do National Health Service ${ }^{57}$.

53 S. Pompl, S. Gherghina, op. cit., s. 449-453.

${ }^{54}$ L. Reed, The UK's Emotional Brexit Journey, 2020, https://www.brandwatch.com/blog/react-the-uks-emotional-brexit-journey/ (dostęp: 15.03.2020).

55 https://www.crowdfunder.co.uk/ (dostęp: 15.03.2020).

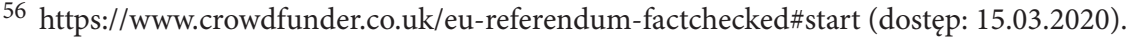

57 https://www.crowdfunder.co.uk/brexit-is-it-worth-it (dostęp: 15.03.2020). 
Znaczna część zbiórek miała charakter informacyjny, a ich celem było uzbieranie środków finansowych na wyprodukowanie filmów informacyjnych, które miały być udostępniane na Facebooku ${ }^{58}$.

Olbrzymią popularnością cieszyły się również zbiórki aktywistów Drew Galdona, Mike’a Gaswortha oraz Madeleiny Kay, której pies Alba White Wolf stał się symbolem pozostania Wielkiej Brytanii w Unii Europejskiej ${ }^{59}$. Aktywiści zbierali środki finansowanie oraz poparcie ludzi, czego rezultatem były liczne happeningi oraz eventy euroentuzjastów, którzy chcieli przekonać resztę społeczeństwa, aby Wielka Brytania pozostała w Unii Europejskiej ${ }^{60}$.

Wiele inicjatyw crowdfundingowych powstało przeciwko Borisowi Johnsonowi, który bardzo szybko stał się jednym z symboli wyjścia Wielkiej Brytanii z Unii Europejskiej. Celem zbiórek było sfinansowane licznych strumieni komunikacji, od tych umieszczonych na bilbordach, po posty i filmy informacyjne udostępniane na platformach społecznościowych. Co istotne, inicjatorzy podkreślali, że są autonomicznym ruchem oddolnym, który reprezentuje młode pokolenie i nie zgadza się na konserwatywną politykę Borisa Johnsona. W ciągu ośmiu dni zbiórkę wsparło 367 osób, co pozwoliło zebrać $11076 \mathrm{GBP}^{61}$.

Prawdziwy potencjał crowdfundingu ukazała zbiórka, której celem było zebranie środków finansowych na obnażenie kłamstw zarzuconych przez euroentuzjastów Borisowi Johnsonowi na temat potencjalnych korzyści z wyjścia Wielkiej Brytanii z Unii Europejskiej. W sześć dni, od 4 do 11 grudnia 2019 roku, 13950 osób przekazało łącznie 324683 tysięcy GBP. Główną inicjatywą zbiórki było zebranie środków na reklamy o charakterze społeczno-politycznym umieszczane w mediach społecznościowych oraz na blokach i bilbordach, mające na celu ukazanie konsekwencji wyjścia Wielkiej Brytanii z Unii Europejskiej. Dzięki zgromadzonym środkom finansowym inicjatorzy stworzyli film, który został wyświetlony 2 lutego 2020 roku na tarczy zegarowej wieży Big Ben w Londynie. Film przedstawiał urywki wypowiedzi takich polityków jak Nigel Farage oraz Boris Johnson podczas brexitowej kampanii oraz zaraz po jej zakończeniu. Monologi polityków były przeplatane migawkami obrazującymi narastającą falę nienawiści w kraju, która przejawiała się między innymi dyskryminacją Polaków pracujących na wyspach ${ }^{62}$.

Na sfinansowanie kampanii prounijnej za pomocą narzędzi crowdfundingowych zdecydował się Ruch Europejski, który ma sto dwadzieścia sześć lokalnych grup w każdym regionie Wielkiej Brytanii i jest największą oddolną organizacją proeuropejską na wyspach. 11 września 2017 roku przy wsparciu 1736 osób udało im się zebrać 52032 tysięcy GBP na materiały promocyjne ${ }^{63}$.

\footnotetext{
58 https://www.crowdfunder.co.uk/thebrexitvideo (dostęp: 15.03.2020).

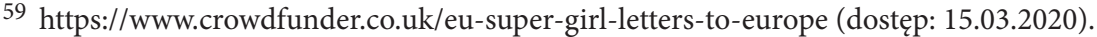

$60 \mathrm{https} / / /$ www.crowdfunder.co.uk/fauxbojo (dostęp: 15.03.2020).

$61 \mathrm{https://www.crowdfunder.co.uk/youthcan2019} \mathrm{(dostęp:} \mathrm{15.03.2020).}$

62 https://www.crowdfunder.co.uk/by-donkeys\#start (dostęp: 15.03.2020).

63 https://www.crowdfunder.co.uk/fight-brexit-war-chest (dostęp: 15.03.2020).
} 
Partia Zielonych w grudniu 2019 roku za pomocą platformy crowdfunder.co.uk zebrała 286020 tysięcy GBP na poczet kampanii parlamentarnej. W czasie kilkuetapowego przedsięwzięcia, które trwało sześćdziesiąt dziewięć dni, Zielonych wsparło 5685 osób. Zgromadzone środki miały zostać przeznaczone między innymi na tworzenie filmów promocyjnych, zatrudnienie większej liczby pracowników podczas kampanii, drukowanie ulotek, aktywizowanie grup wolontariuszy, rozszerzanie zasięgów w mediach społecznościowych. W opisie kampanii crowdfundigowej Zieloni odwoływali się zarówno do bieżących problemów społeczno-politycznych w Wielkiej Brytanii, jak i zagrożeń związanych ze zmianami klimatu i konsekwencjami wyjścia Wielkiej Brytanii z Unii Europejskiej. Warto podkreślić, że Zieloni informowali swoich darczyńców o regulacjach związanych z przekazywaniem darowizn na swoich stronach internetowych ${ }^{64}$.

\section{Zakończenie}

Wzrost roli udziału społeczeństwa w polityce jest ważnym determinantem rozwoju koncepcji opartych na takich mechanizmach jak crowdfunding czy crowdsourcing. Zastosowanie mechanizmów politycznego crowdfundingu może być odpowiedzią na brak zasobów ludzkich oraz finansowych przy jednoczesnym podkreśleniu znaczenia zwykłych obywateli w procesach decyzyjnych, zarówno na poziomie lokalnym, jak i krajowym czy ponadnarodowym. Polityczny crowdfunding może pełnić funkcję brakującego ogniwa w procesie komunikacji pomiędzy społecznością a politycznymi decydentami, umożliwiając zbieranie środków finansowych oraz wymianę doświadczeń i opinii na określony temat. Polityczny crowdfunding umożliwia wsparcie danej inicjatywy politycznej lub prospołecznej, które z uwagi na swój charakter nie miałyby szans zostać sfinansowane w tradycyjny sposób.

Polityczny crowdfunding stał się realnym narzędziem w walce o interesy grup, które w pewnym wymiarze zostały pozbawione możliwości kreowania społecznej oraz politycznej rzeczywistości. Narzędzia crowdfundingowe pozwoliły podjąć wiele prospołecznych inicjatyw w Wielkiej Brytanii w okresie brexitu, w wyniku których opinia publiczna została poinformowana o dezinformacyjnej kampanii medialnej w obszarze służby zdrowia czy polityki migracyjnej kraju.

W wielu krajach europejskich polityczny crowdfunding coraz chętniej wybierany jest jako jedna $\mathrm{z}$ form kampanii politycznych, w szczególności przez kandydatów spoza establishmentu politycznego. Pozwala on danemu politykowi czy działaczowi społecznemu pobudzić swoją kampanię w jej początkowej fazie rozwoju. Część partii politycznych wykorzystuje crowdfunding do pokrycia pierwszych wydatków związanych z uruchomieniem kampanii wyborczej - to zdecydowanie zwiększa szanse kandydatów, którzy mogą szybciej przejść do kolejnych etapów kampanii oraz realizować założone zadania.

64 https://www.crowdfunder.co.uk/greens2parliament\#start (dostęp: 15.03.2020). 
Dalszy rozwój narzędzi crowdfundingowych i ich udział w kampaniach politycznych oraz społecznych będzie w dużej mierze uzależniony od rozwoju internetowej infrastruktury. Brak przejrzystości oraz duże pole do nadużyć mogą negatywnie wpłynąć na rozwój politycznego crowdfundingu, skutecznie hamując jego dalszą ewolucję.

\section{Bibliografia}

\section{Literatura}

Belleflamme P. et. al., Crowdfunding: Tapping the right crowd, „Journal of Business Venturing” 2014. Blumler J.G., Coleman S.J., The Internet and Democratic Citizenship: Theory, Practice and Policy, Cambridge 2009.

Calderaro A., Internet Governance Capacity Building in Post-Authoritarian Contexts. Telecom Reform and Human Rights in Myanmar, New York 2015.

Calderaro A., Social media and politics, [w: ] The SAGE Handbook of Political Sociology, red. W. Outhwaite, S.P. Turner, Cardiff 2018.

Cammaerts B., Internet-Mediated Participation Beyond the Nation State, Manchester 2008.

de Buysere K. et al., A framework for European crowdfunding, European Crowdfunding Network 2012.

Freund R., How to overcome the barriers between economy and sociology with open innovation, open evaluation and crowdfunding?, „International Journal of Industrial Engineering and Management", Novi Sad 2010.

Gerber E., Kuo P.Y., Design principles. crowdfunding as a creativity support tool, ACM. In Proceeding CHI'12, Extended Abstracts on Human Factors in Computing Systems 2012.

Gibson R.K., Party change, social media and the rise of 'citizen-initiated' campaigning, „Party Politics” 21, 2015, nr 2.

Hassell H.J.G., Monson J.Q., Campaign targets and messages in direct mail fundraising, „Polit Behav" 36, 2014.

Hemer J., A snapshot on crowdfunding, „Working Paper Firms and Region” 2011.

Hill S.J., Huber G.A., Representativeness and motivations of the contemporary donorate: Results from merged survey and administrative records, „Polit Behav” 39, 2017.

Howard P.N., Hussain M.M., Democracy's Fourth Wave?: Digital Media and the Arab Spring, New York 2013.

International Institute for Democracy and Electoral Assistance, Online Political Crowdfunding Political Party Innovation Primer 2, International IDEA, Sweden 2018.

Johnston R., Pattie C., Money and Electoral Politics: Local Parties and Funding at General Elections, Bristol 2014.

Khoma N., Technologies of Political (Socio-Political) Crowdsourcing and Crowdfunding: Word Experience and Steps Towards Implementation in Ukraine, Torun 2015.

Natale S., Ballatore A., The web will kill them all: New media, digital utopia, and political struggle in the Italian 5-star movement, „Media, Culture \& Society” 2014.

Norris P., A Virtuous Circle: Political Communications in Postindustrial Societies, Cambridge 2000.

Pompl S., Gherghina S., Messages and familiar faces: Crowdfunding in the 2017 U.K. Electoral Campaign, „Politics \& Policy” 47, 2019, nr 3.

Putnam R.D., Bowling Alone: The Collapse and Revival of American Community, New York 2000.

Scholz N., The Relevance of Crowdfunding The Impact on the Innovation Process of Small Entrepreneurial Firms, Manchester 2015. 


\section{Akty normatywne}

European Commission, Legislative proposal for an EU framework on crowd and peer to peer finance, Brussels 2018.

\section{Źródła internetowe}

http://www.nachrichten.at/nachrichten/politik/innenpolitik/Kurz-betreibt-Crowdfunding;art385, 2612125.

https://www.brandwatch.com/blog/react-the-uks-emotional-brexit-journey.

https://www.crowdfunder.co.uk/.

https://www.crowdfunder.co.uk/brexit-is-it-worth-it.

https://www.crowdfunder.co.uk/by-donkeys\#start.

https://www.crowdfunder.co.uk/eu-referendum-factchecked\#start.

https://www.crowdfunder.co.uk/eu-super-girl-letters-to-europe.

https://www.crowdfunder.co.uk/fauxbojo.

https://www.crowdfunder.co.uk/fight-brexit-war-chest.

https://www.crowdfunder.co.uk/greens2parliament\#start.

https://www.crowdfunder.co.uk/thebrexitvideo.

https://www.crowdfunder.co.uk/youthcan2019.

https://www.pirati.cz/tiskove-zpravy/piratska-lod-vyplouva.html. 